\title{
The Effect of Low Dose Ionizing Radiation and Cadmium Chloride on Glucose Metabolism in Broiler Chickens
}

\author{
Denisa Daňová1, Igor Kafka ${ }^{1}$, Zuzana Kaleničová1, Jaroslava Novákováa \\ ${ }^{1}$ Institute of Biology, Zoology and Radiobiology, University of Veterinary Medicine Košice, Slovak Republic \\ ${ }^{2}$ Department of Pathological Physiology, Faculty of Medicine, Pavol Jozef Šafárik University in Košice, \\ Slovak Republic
}

Received August 13, 2009

Accepted December 3, 2009

\begin{abstract}
The aim of the study was to observe the effect of ionizing radiation and cadmium chloride on glucose metabolism in broiler chickens. The experiment was conducted on 28-day-old chickens divided into four groups (A, B, C and D). The first group (A) served as control, groups 2 (B) and 3 (C) were irradiated with a single, whole body dose of gamma rays ( $3 \mathrm{~Gy}$, input $\left.1.14 \mathrm{~Gy} \cdot \mathrm{min}^{-1}\right)$ and group 3 (C) was administered a water solution of $\mathrm{CdCl}_{2}$ intraperitoneally at a dose of $6 \mathrm{mg} \cdot \mathrm{kg}^{-1}$ body weight. Group 4 (D) was administered a water solution of $\mathrm{CdCl}_{2}$ intraperitoneally at the same dose as group 3 but chickens of this group were not irradiated with gamma rays. The serum glucose concentration in the chickens that were irradiated and administered $\mathrm{CdCl}_{2}$ solution $(\mathrm{C})$ was decreased significantly $(p<0.05)$ on days 7,14 and $21(p<0.01)$ of the experiment compared to control (A). The serum glucose concentration in the chickens administered only $\mathrm{CdCl}_{2}$ (D) was decreased significantly on day 7 compared to control (A). No significant changes in serum glucose concentrations were observed in the remaining group. The results of our experiment indicate that a combined influence of ionizing radiation and administered cadmium chloride resulted in a significant decrease in serum glucose concentration and the influence was more evident than that caused either by cadmium chloride or irradiation alone. The changes in serum glucose concentration observed on days 7 and 14 in gamma-irradiated chickens were lower than those induced only by administration of cadmium chloride.
\end{abstract}

Glucose, gamma irradiation, cadmium

Study of the effects of ionizing radiation on live organisms in the era of intensive use of nuclear energy and ionizing radiation in medical diagnostics and information technologies is an important activity aiming to protect the health of human population. Industrial production and urbanization are responsible for increased pollution of our ecosystem with toxic substances including risk elements (Beyer et al. 2005; Obi et al. 2006). Cadmium is a highly toxic, dangerous environmental contaminant capable of accumulating in soil and water ecosystems (Drastichová et al. 2004) through which it enters also the food chain (Altindag and Yigit 2005; Johansen et al. 2006). It is dangerous because of its ability to accumulate in the body, particularly in the liver and kidneys.

The combined effects of ionizing radiation and heavy metals on organisms may differ from those caused by either of them alone and result in synergistic or antagonistic action. Only a limited number of studies have been focused on interactions of ionizing radiation and chemical substances that are present in the environment, and on their potential impact on live organisms. Few authors have investigated the combined effects of ionizing radiation and cadmium chloride on the living organism.

\section{Materials and Methods}

The experiment was carried out on broiler hybrid of domestic fowl (Gallus gallus), 28 days old. A total of 72 broilers were included in the experiment. The chickens were placed to previously disinfected facilities and left to adapt for one week to experimental conditions. The chickens were supplied water and feed ad libitum. They were fed granulated mixed feed for chickens BR I and BR II (Beňová et al. 2003).

Address for correspondence:

MVDr. Denisa Daňová, PhD

University of Veterinary Medicine in Košice

Institute of Biology, Zoology and Radiobiology

Phone: +421904413986

Komenského 73,041 81 Košice, Slovak Republic

E-mail: danova@uvm.s

http://www.vfu.cz/acta-vet/actavet.htm 
Irradiation was carried out in adjusted plexit cages at the Faculty of Natural Sciences of Pavol Jozef Šafárik University in Košice, Slovak Republic using the apparatus CHISOSTAT ${ }^{60} \mathrm{Co}$-Chirana. The entire experiment was approved by the Ethics Committee of the Slovak Republic.

At the beginning of the experiment, the chickens were divided at the age of 28 days into four groups, 18 birds in each. Group 1 (A) served as control, group 2 (B) was irradiated with gamma rays using a single, whole body dose of 3 Gy (input $1.14 \mathrm{~Gy} \cdot \mathrm{min}^{-1}$ ). Group 3 (C) was administered saline supplemented with $\mathrm{CdCl}_{2}$ intraperitoneally at a dose of $6 \mathrm{mg} \cdot \mathrm{kg}^{-1}$ b.w. (dose of $\mathrm{Cd}^{2+} 3.07 \mathrm{mg}$ ) and simultaneously irradiated as group B. Group 4 (D) was administered saline supplemented with $\mathrm{CdCl}_{2}$ intraperitoneally at the same dose as group 3 (C) without irradiation.

On days 7, 14 and 21 post-irradiation 6 birds from each group were euthanized. Serum glucose concentration was determined by means of Pliva Lachema test, Czech Republic. Measurements were carried out on a spectrophotometer Specol 11. The results obtained at individual time intervals were processed statistically by ANOVA test (PRISM3 SOFTWARE).

Our experiment was focused on observing the effect of cadmium chloride and irradiation with a low dose of gamma rays on glucose metabolism in broiler chickens and the potential subsequent impact on the bird health. The experiment was carried out on domestic fowl as a model animal; this species is particularly interesting because of its increased radiation resistance compared to other farm animals (Beňová et al. 2007).

\section{Results}

The concentration of serum glucose determined at time intervals of 7, 14 and 21 days in individual groups of broiler chickens are presented in Fig. 1.

The glucose concentration in serum of the chickens that were irradiated and administered solution of $\mathrm{CdCl}_{2}$ (group $\mathrm{CdCl}_{2}$ and irradiated decreased significantly $(p<0.05)$ compared to chickens from control group on days 7, 14 and $21(p<0.01)$ of the experiment. In chickens from group administered only $\mathrm{CdCl}_{2}$ solution, the concentration of glucose decreased significantly $(p<0.05)$ only on day 7. The concentration of glucose in chickens from irradiated group showed no significant changes compared to control.

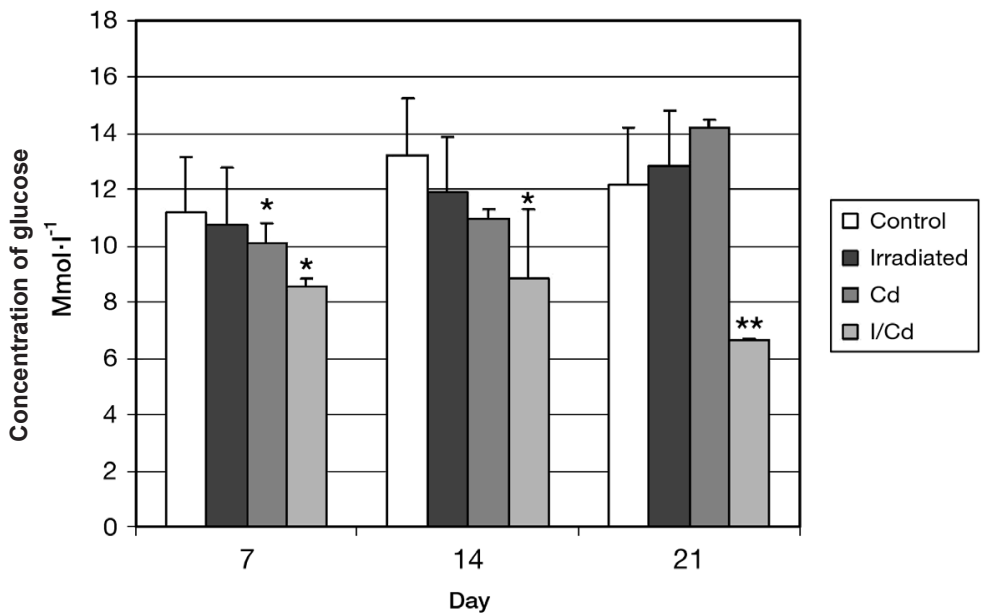

Fig. 1. The effect of ionizing radiation and cadmium chloride on glucose metabolism in broiler chickens

\section{Discussion}

The result of our experiment showed that ionizing radiation in combination with administered cadmium chloride decreased significantly the serum glucose concentration in broiler chickens and the decrease was more evident than that caused by cadmium chloride or irradiation alone. The irradiation itself caused lower changes in glucose concentration on days 7 and 14 than administration of cadmium chloride. 
Slovinská et al. (2001) studied the effect of cadmium and ionizing radiation on the haemopoietic tissue, liver and kidneys of rats. Cadmium alone caused more extensive changes in the kidneys and liver than ionizing radiation. The effect of combination of ionizing radiation and cadmium was similar to those induced by cadmium only. Marked pathological changes were observed in the bone marrow, spleen and thymus of irradiated animals compared to the effect of cadmium; the patological changes caused by a combination of ionizing radiation and cadmium were similar to those induced by irradiation alone.

Klímová and Mišúrová (2004) observed changes in histones in rat testes after administration of cadmium $\left(\mathrm{CdCl}_{2}\right.$ at a dose of $3 \mathrm{mg} \cdot \mathrm{kg}^{-1}$ body weight, i.p. $)$ and whole body irradiation with gamma rays (3 Gy). They observed that administration of cadmium alone caused no changes in histones (protein) while irradiation induced an increase in the initial concentration and total content of histones. Combination of cadmium and irradiation (cadmium administered $30 \mathrm{~min}$ before irradiation) caused changes in histones similar to those induced by irradiation alone, but more intensive. This finding indicated partial summation of the effects of both cadmium and irradiation on testis histones. A radiationprotective effect of cadmium in combination with ionizing radiation was described by Dvořák and Beňová (2002) who observed the effect of cadmium chloride, potassium dichromate and gamma radiation on the crustacean Artemia salina. After single exposure to doses $0.1,0.25,0.5$ and $1.0 \mathrm{kGy}$ and observation period of $120 \mathrm{~h}$ the authors detected a radiation-protective effect of cadmium chloride at a concentration of $20 \mathrm{mg} \cdot \mathrm{l}^{-1}$ and of potassium dichromate at a concentration of $5 \mathrm{mg} \cdot \mathrm{l}^{-1}$. Cadmium alone had no lethal effect on the crustacean.

The protective influence of exposure to cadmium is affected decisively by low molecular weight protein metallothionein (Klaassen et al. 2009). Cadmium, ionizing radiation, glucocorticoids and cytokines belong to factors that increase significantly the production of metallothionein in the body (Rogival et al. 2007).

Experiments on mammals show that several hours after irradiation there is a socalled postradiation hyperglycaemia that culminates between the first and third day after irradiation. The rise of hyperglycaemia after irradiation is not attributed to the primary role of the hypothalamic-pituitary-adrenal and/or glucocorticoids, but mainly to increased gluconeogenesis from amino acids that are released from tissue proteins after irradiation (Toropila 1993). Compared to mammals, however, glucose concentrations in serum decreased in our experiment on poultry. One possible explanation is the difference in species and different morphological constructions, or physiological functions. An important factor in the development of metabolic changes after irradiation is also the absorption of glucose and other sugars in the intestine, which is reduced by different doses (Toropila et al. 1984). Apart from the effect of radiation, the type of food administered to animals before or after irradiation may have a major impact on carbohydrate metabolism.

The results of this study bring new information in the field of radiobiology, toxicology and radioecology in terms of the effects of more than one contaminant on the animal organism.

\section{Účinok nízkej dávky ionizujúceho žiarenia a chloridu kademnatého na metabolizmus glukózy u brojlerových kurčiat}

V experimente bol sledovaný účinok ionizujúceho žiarenia a vplyvu chloridu kademnatého na metabolizmus glukózy u brojlerových kurčiat. Kurčatá boli rozdelené do štyroch skupín, vo veku 28 dní na začiatku experimentu. Prvá skupina kurčiat bola intaktná. Druhá a tretia skupina kurčiat bola ožiarená jednorazovou celotelovou dávkou 3 Gy gama lúčov (príkon 1,14 Gy·min ${ }^{-1}$ ), tretej skupine kurčiat bol súčasne intraperitoneálne aplikovaný fyziologický roztok doplnený o $\mathrm{CdCl}_{2}$ o koncentrácii $6 \mathrm{mg} \cdot \mathrm{kg}^{-1}$ živej hmotnosti. Štvrtej 
skupine kurčiat bol intraperitoneálne aplikovaný fyziologický roztok doplnený o $\mathrm{CdCl}_{2}$ o koncentrácii $6 \mathrm{mg} \cdot \mathrm{kg}^{-1}$ živej hmotnosti bez celotelového ožiarenia. Koncentrácia glukózy v sére ožiarených kurčiat $\mathrm{s}$ aplikovaným roztokom $\mathrm{CdCl}_{2}$ bola na 7., 14. a 21. deň významne znížená v porovnaní s kontrolnou skupinou kurčiat. Koncentrácia glukózy v sére kurčiat iba $\mathrm{s}$ aplikovaným roztokom $\mathrm{CdCl}_{2}$ bola na 7 . deň významne znížená v porovnaní s kontrolnou skupinou kurčiat.

V ostatných sledovaných skupinách zvierat nedošlo k významným zmenám koncentrácie glukózy v sére kurčiat.

Z výsledkov nášho experimentu vyplýva, že vplyv ionizujúceho žiarenia v kombinácii s podaným kadmiom výrazne znižuje koncentráciu glukózy v krvi u kurčiat ako samotne podané kadmium, resp. samotné ožiarenie. Samotné žiarenie vyvolalo menšie zmeny v koncentrácii glukózy v krvi na 7. a 14. deň ako aplikácia len samotného kadmia.

\section{Acknowledgement}

The study was supported by project Vega 1/2378/05.

\section{References}

Altindag A, Yigit S 2005: Assessment of heavy metal concentrations in the food web of lake Beysehir, Turkey. Chemosphere 60: 552-556

Beňová K, Toropila M, Falis M, Dvořák P 2003: Influence of ionising radiation on the activity of selected adaptive enzymes in chickens and rats. Acta Vet Brno 72: 201-205

Beňová K, Dvořák P, Falis M, Sklenář Z 2007: Interaction of low doses of ionizing radiation potassium dichromate and cadmium chloride in Artemia franciscana biotest. Acta Vet Brno, 76: 35-40

Beyer WN, Dalgarn J, Dudding S, French JB, Mateo R, Miesner J, Sileo L, Spann J 2005: Zinc and poisoning in wild birds in the Tri-State Mining District (Oklahoma, Kansas, and Missouri) Arch Environ Contam Toxicol 48: $108-117$

Drastichová J, Svobodová Z, Lúsková V, Máchová J 2004: Effects of cadmium on haematological indices of common carp (Cyprinus carpio L.). Bull Environ Contam Toxicol 72: 725-732

Dvořák P, Beňová K 2002: The investigation of interaction of low doses of ionizing radiation and risk factors by means of Artemia salina biotest. Folia Vet 46: 195-197

Johansen P, Mulvad G, Pedersen HS, Hansen JC, Riget F 2006: Accumulation of cadmium in livers and kidneys in Greenlanders. Science of the Total Environ 372: 58-63

Klaassen CD, Liu J, Diwan BA 2009: Metallothionein protection of cadmium toxicity. Toxicol Appl Pharmacol, Kansas, USA 238: 215-220

Klímová S, Mišúrová E 2004: Effects of cadmium and ionizing radiation on histones in rat testes. Acta Vet Brno 73: 483-489

Obi E, Akunyili DN, Ekpo B, Orisakwe OE 2006: Heavy metal hazards of Nigerian herbal remedies. Sci Total Environ 369: 3541

Rogival D, van Campenhout K, Infante HG, Hearn R, Scheirs J, Blust R 2007: Induction and metal spatiation of metallotionein in wood mince (Apodemus sylvaticus) along a metal pollution gradient. Environ Toxicol Chem 26: $506-514$

Slovinská L, Kropáčová K, Kolesárová M, Mišúrová E 2001: Effects of combined treatment of rats with cadmium and ionizing radiation on acids in the kidneys, liver and haemopoietic organs, Folia Biol (Praha) 47: 92-100

Toropila M 1993: Practical Lessons in Radiobiology, Magnus, Košice, 75 p.

Toropila M, Ahlers I, Ahlersová E, Ďatelinka I, Praslička M 1984: Effect of restricted feeding on metabolic changes in lipids following a single lethal irradiation of rats. Radiobiologija 24: 794-797 